\title{
DESAIN SIMULASI MAKSIMUM POWER POINT TRACKING METODE P\&O PADA PANEL SURYA DI AZZAHRA HIDROPONIK JUATA TARAKAN
}

\author{
Abil Huda ${ }^{1}$, Wahyudi Siraju ${ }^{2}$ \\ ${ }^{12}$ Universitas Borneo Tarakan, Tarakan, Kaltara, Indonesia \\ Iabil@engineer.com
}

\begin{abstract}
Abstact - Solar panels are electricity generators that utilize solar energy. One of them is the Azzahra Hydroponic solar panel with a capacity of $200 \mathrm{Wp}$ which has a non-linear output. According to Amri, (2015) this is due to the changing conditions of the sun. To solve the non-linear problem of solar panels, there are 2 types of controllers, namely PWM and MPPT. This study uses the Perturb \& Observe $(P \& O)$ method because this method is simpler, has efficiency and a high level of accuracy compared to other methods (Kesler, 2016). Under conditions of intensity $S=1000$ and temperature $T=40^{\circ}$, Pmax is 201.5 W, Po is 201.1 W and the time required for MPPT to track is 0.003 seconds, at $S=500 T=25$, Pmax $=97,7$ $W$ and $P o=96.4 W$ and the time required is 0.006 seconds. And in the condition $S=100 T=10$ obtained Pmax $=9.4 \mathrm{~W}$, $P o=9.3 \mathrm{~W}$ and the time required for MPPT to track is 0.04 seconds. Based on the simulation results, it can be concluded that the maximum power point tracking (MPPT) simulation design using the perturb and observe $(P \& O)$ method was successful and MPPT was able to track the maximum power on Azzahra Hydroponic solar panels under conditions of varying intensity and temperature.
\end{abstract}

Keywords: Buck Converter, MPPT, P\&O, Solar Panel

Intisari - Panel surya merupakan pembangkit listrik yang memanfaatkan energi cahaya matahari. Salah satunya panel surya Azzahra Hidroponik dengan kapasitas 200 Wp yang mempunyai keluaran yang non-linear. Menurut Amri, (2015) hal ini disebabkan oleh kondisi matahari yang berubah-ubah. Untuk menyelesaikan masalah non-linear dari panel surya terdapat 2 jenis controller yaitu PWM dan MPPT. Penelitian ini menggunakana metode Perturb \& Observe (P\&O) di karenakan metode ini lebih sederhana, memiliki efisiensi dan tingkat akurasi yang tinggi dibandingkan metode lainnya (Kesler, 2016). Pada kondisi intensitas $S=1000$ dan suhu $T=40^{\circ}$ didapatkan Pmax 201,5 W, Po 201,1 W dan waktu yang dibutuhkan MPPT untuk men-track adalah 0,003 detik, pada saat $\mathrm{S}=500 \mathrm{~T}=25$ maka didapatkan $P \max =97,7 \mathrm{~W}$ dan $P o=96,4 \mathrm{~W}$ dan waktu yang dibutuhkan adalah 0,006 detik. Dan pada kondisi $S=100$ $\mathrm{T}=10$ didapatkan $\mathrm{Pmax}=9,4 \mathrm{~W}, \mathrm{Po}=9,3 \mathrm{~W}$ dan waktu yang dibutuhkan MPPT untuk men-track adalah 0,04 detik.

Berdasarkan hasil simulasi yang dilakukan, maka dapat disimpulkan bahwa desain simulasi maksimum power point tracking (MPPT) menggunakan metode perturb and observe (P\&O) berhasil dan MPPT dapat men-track daya maksimum pada panel surya Azzahra Hidroponik dalam kondisi intensitas dan suhu yang berbeda-beda.

Kata Kunci: Buck Converter, MPPT, P\&O, Panel Surya

\section{PENDAHULUAN}

Di Indonesia panel surya banyak digunakan untuk menyuplai kebutuhan listrik, dimana kebutuhan listrik bermacam-macam seperti penerangan lampu, pompa air dan lain-lain. Panel surya ini merupakan pembangkit listrik memanfaatkan energi terbarukan berupa cahaya matahari. Salah satunya di panel surya AZZAHRA HIDROPONIK dengan kapasitas $200 \mathrm{Wp}$ yang juga mempunyai keluaran yang non-linear. Menurut Amri, (2015) hal ini disebabkan oleh kondisi matahari yang berubah-ubah. Untuk menyelesaikan masalah non-linear dari panel surya terdapat 2 jenis controller yaitu PWM dan MPPT. Dari hasil pengujian alat, diketahui bahwa daya keluaran controller MPPT ini lebih efisien dibandingkan dengan controller PWM. Maka dari itu dalam penelitian ini menggunakan controller MPPT untuk menghasilkan daya maksimal yang diperoleh panel surya.

Pada penelitian ini menggunakana algoritma metode Perturb \& Observe $(\mathrm{P} \& \mathrm{O})$ di karenakan metode $\mathrm{P} \& \mathrm{O}$ lebih sederhana memiliki efisiensi yang tinggi dan memiliki tingkat akurasi yang tinggi dibandingkan metode lainnya (Kesler, 2016).

Penelitian ini mensimulasikan sistem sel surya menggunakan MPPT metode P\&O di Azzahra Hidroponik Kelurahan Juata Laut menggunakan PSIM, karena di lokasi Azzahra Hidroponik tempat panel surya yang terpasang kondisi geografisnya terbuka dari gedunggedung dan pohon, sehingga dapat mempengaruhi temperature dan suhu hal ini juga diperkuat oleh Suryana dan Ali (2016) yang mengungkapkan bahwa tegangan listrik yang di hasilkan oleh panel surya tidak hanya bergantung pada besarnya intensitas radiasi yang di terima namun temperatur dan suhu pada permukaan panel surya dapat mempengaruhi tegangan yang dihasilkan panel surya. Sehingga peneliti ingin merancang desain simulasinya menggunakan aplikasi PSIM sesusai dengan judul penelitian.

\section{LANDASAN TEORI}

\section{A. Karakteristik Panel Surya}

Daya keluaran sel surya merupakan fungsi non-linear terhadap temperatur dan intensitas cahaya. Gambar 1 dan 2 menunjukkan hubungan antara temperatur terhadap 
daya output dan intensitas terhadap daya keluaran sel surya. Gambar 2 mengilustrasikan daya keluaran sel surya naik sesuai dengan nilai intensitas cahaya yang diterimanya. Untuk nilai temperatur dan radiasi yang berbeda, masing-masing daya keluaran maksimum akan diperoleh dan diketahui sebagai Maximum Power Point (MPP). (a)

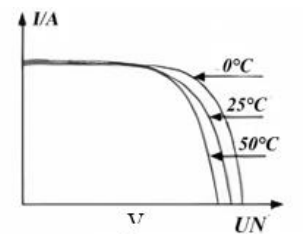

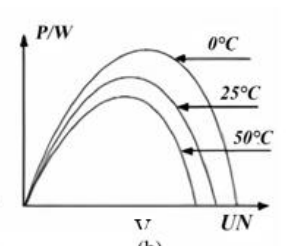

(b)
Gambar 1. Karakteristik arus-tegangan dan daya-tegangan sel surya untuk temperatur yang berbeda

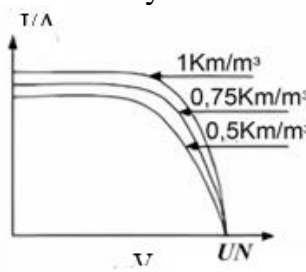

(a)

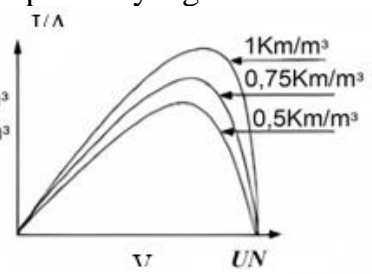

(b)
Gambar 2. Karakteristik Arus-Tegangan dan Daya-

Tegangan Sel Surya Untuk Intensitas yang Berbeda.

Gambar 1 dan 2 mengilustrasikan karakteristik daya keluaran sel surya selalu berubah sesuai dengan temperatur dan intensitas cahaya yang diterimanya. Untuk mencapai daya keluaran maksimum untuk setiap kondisi yang bervariasi. Panel surya dapat mengadopsi kontroler maximum power point (MPP) [1].

\section{B. Buck Converter}

Buck converter adalah Dc-Dc converter jenis penurun tegangan atau step down. Buck converter mampu menghasilkan nilai tegangan output sama atau lebih rendah dari tegangan input-nya. Buck converter ini tersusun dari mosfet (saklar aktif) dan dioda (saklar pasif). Saklar pasif dapat diganti dengan aktif pada saat tegangan kerja yang rendah, Sehingga dapat mengurangi daya susut yang terjadi [2].

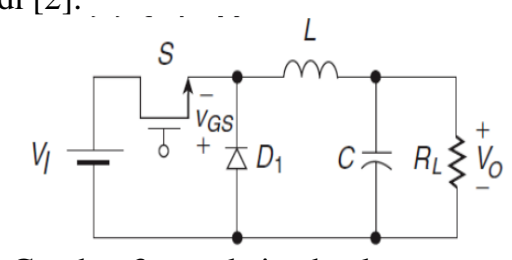

Gambar 3. rangkaian buck converter

$$
\begin{aligned}
& D=\frac{T_{O N}}{T}=\frac{T_{O N}}{T_{O N O}+T_{O E E}}=f_{S} T_{O N} \\
& i_{L}=\frac{\left(r_{L}+r_{m}\right)\left(R+r_{G}\right)+\left(r_{m i}-r_{d}\right)\left(R+r_{G}\right)^{l}}{L\left(R+r_{C}\right)} \\
& V_{C}=\frac{R D}{\left(R+Y_{L}\right) C} i_{L}-\frac{L\left(R+V_{C} V_{L}\right.}{\left(R+Y_{L}\right) C}-\frac{R}{\left(R+Y_{C L}\right)}
\end{aligned}
$$

Keterangan:

$D \quad=$ Duty cycle ketika off

$i_{L} \quad=$ Arus pada induktor

$V_{C} \quad=$ Tegangan pada kapasitor

C. Aki
Aki adalah sebuah sumber arus listrik searah yang dapat mengubah energi kimia menjadi energi listrik. Aki termasuk elemen elektrokimia yang dapat mem-pengaruhi zat pereaksinya, sehingga disebut elemen sekunder. Aki pertama kali ditemukan oleh ahli fisika Perancis, bernama Gaston Plante pada tahun 1859 (Setiono, 2015).

Bagian-bagian utama aki adalah :

1. Kutub positip (anode), ternuat dari timbal dioksida $(\mathrm{Pb}$ $\mathrm{O} 2)$

2. Kutub negative, (katode), terbuat dari timbal murni $(\mathrm{Pb})$

3. Larutan elektrolit, terbuat dari asam sulfat (H2SO4)

\section{Maksimum power Point Tracking (MPPT)}

Maximun power point tracking atau yang disingkat MPPT, adalah sebuah sistem elektronis yang mengoperasikan modul sel surya agar dapat menghasilkan daya maksimal yang bisa diproduksi oleh modul sel surya. MPPT bukan merupakan sistem tracking mekanis yang secara fisik menggerakkan modul agar mengarah langsung ke matahari. MPPT merupakan sistem elektronis yang secara keseluruhan mengubah titik operasi elektronis modul sel surya sehingga dapat mengirim daya maksimal yang tersedia. Dari daya tambahan yang terkumpul yang berasal dari modul sel surya, sehingga arus pengisian baterai dapat ditingkatkan. MPPT dapat juga dihubungkan dengan sistem tracking mekanis, tetapi kedua sistem ini benar-benar sangat berbeda (Faisal dan Setyaji, 2016).

\section{E. Perturb and Observe (P\&O)}

Metode perturb and observe $(\mathrm{P} \& \mathrm{O})$ dapat digunakan untuk menentukan titik optimum. Dengan menggunakan metode $\mathrm{P} \& \mathrm{O}$, nilai daya maksimum bisa didapatkan tanpa harus mengetahui karakteristik dari sistem sel surya. Nilai daya maksimum didapatkan dengan cara mengatur besaran tegangan dc pada konverter. Dengan perubahan besar tegangan dc pada konverter, maka nilai daya juga akan berubah. Metode ini mengatur dan mengamati setiap perubahan tersebut. Perubahan ditentukan pada step-size $(\Delta \mathrm{D})$ tertentu dan waktu tertentu. Besar nilai daya listrik yang dihasilkan dibandingkan dengan daya listrik sebelumnya. Hal ini menentukan variabel $\Delta \mathrm{D}$ berikutnya. Jika besar nilai daya yang dihasilkan meningkat maka variabel $\Delta \mathrm{D}$ akan bernilai tetap, sebaliknya jika besar nilai daya yang tersedia. Dari daya tambahan yang terkumpul yang berasal dari modul sel surya, sehingga arus pengisian baterai dapat ditingkatkan. MPPT dapat juga dihubungkan dengan sistem tracking mekanis, tetapi kedua sistem ini benar-benar sangat berbeda (Faisal dan Setyaji, 2016).

E. Metode Perturb \& Observe (P\&O)

Metode perturb and observe $(\mathrm{P} \& \mathrm{O})$ dapat digunakan untuk menentukan titik optimum. Dengan menggunakan metode $\mathrm{P} \& \mathrm{O}$, nilai daya maksimum bisa didapatkan tanpa harus mengetahui karakteristik dari sistem sel surya. Nilai daya maksimum di dapatkan dengan cara mengatur besaran tegangan dc pada konverter. Dengan perubahan besar tegangan dc pada konverter, maka nilai daya juga akan berubah. Metode ini mengatur dan mengamati setiap perubahan tersebut. Perubahan ditentukan pada step-size 
$(\Delta \mathrm{D})$ tertentu dan waktu tertentu. Besar nilai daya listrik yang dihasilkan dibandingkan dengan daya listrik sebelumnya. Hal ini menentukan variabel $\Delta \mathrm{D}$ berikutnya. Jika besar nilai daya yang dihasilkan meningkat maka variabel $\Delta \mathrm{D}$ akan bernilai tetap, sebaliknya jika besar nilai daya yang dihasilkan menurun maka variabel $\Delta \mathrm{D}$ akan berubah. Prinsip kerja dari metode ini dapat dilihat berdasarkan Gambar 4.

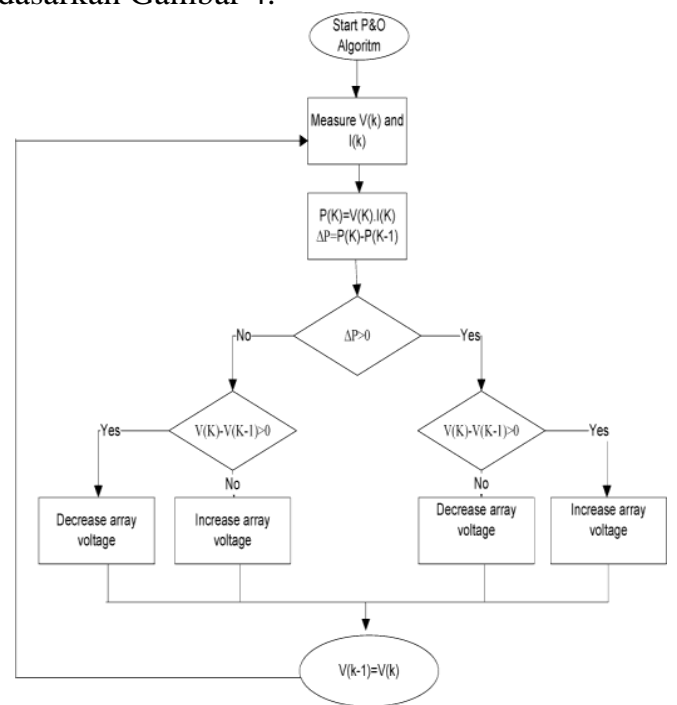

Gambar 4. Flowchart metode perturb and observe

Metode $\mathrm{P} \& \mathrm{O}$ merupakan metode yang paling sederhana dan mudah diaplikasikan diantara metode lainnya. Namun, metode ini memiliki keterbatasan. Tingkat efesiensi dari metode ini tergantung pada besaran variabel $\Delta \mathrm{D}$. Apabila nilai $\Delta \mathrm{D}$ besar maka sistem akan cepat menuju pada nilai maksimum, tetapi akan menghasilkan fluktuasi yang besar saat sudah mencapai nilai maksimum yang mengakibatkan osilasi pada daya yang dihasilkan, sehingga efesiensinya rendah. Jika menggunakan $\Delta \mathrm{D}$ yang kecil maka efesiensi sistem akan lebih baik, tetapi waktu yang dibutuhkan untuk menuju nilai maksimum sangatlah lambat yang mengakibatkan sistem tidak responsif. Algoritma perturb and observe memiliki beberapa parameter sebagai inisialisasi nilai awal dan besar perubahan nilai step size dari setiap iterasi yang dilakukan. Batasan duty cycle juga diperlukan dalam menjalankan algoritma ini dikarenakan untuk menjaga kemampuan.

Dari konverter buck. Waktu tunda dalam menjalankan program dalam satu kali iterasi ditentukan untuk memberikan respon balik akibat perubahan dari nilai duty cycle yang diberikan. Tabel 2.1 menunjukkan parameter yang digunakan pada algoritma perturb and observe (Ernadi, 2016).

Tabel 1

Parameter Algoritma P\&O

\begin{tabular}{ll}
\hline \multicolumn{1}{c}{ Batasan duty cycle } & $\mathbf{0 . 2 - 0 . 8}$ \\
\hline Step size & 0.015 \\
Delay & $0.5-1$ Detik \\
\hline
\end{tabular}

\section{METODE PENELITIAN}

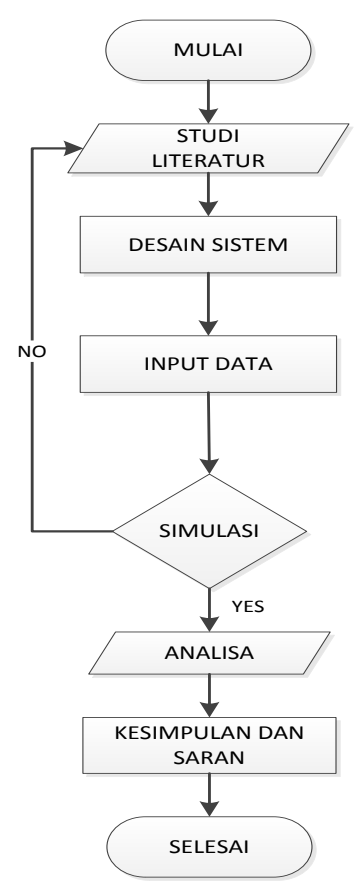

Gambar 5. Diagram Alir Penelitian

\section{A. Diagram Blok Sistem}

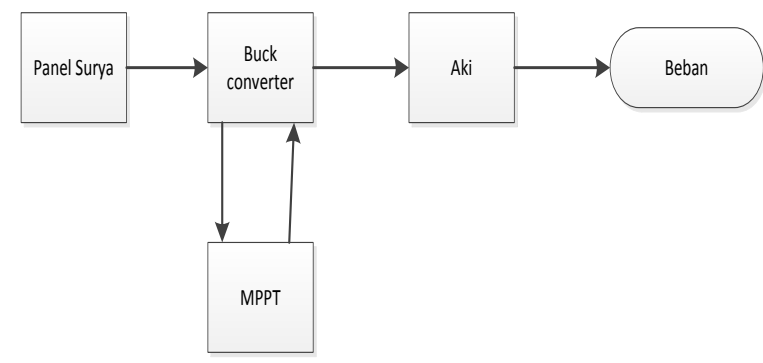

Gambar 6. Diagram Blok Sistem

Tegangan yang akan di hasilkan oleh sel surya akan di olah oleh MPPT yang menggukan algoritma P\&O untuk mendapatkan tegangan maksimum, setelah itu tegangan akan di turunkan oleh Buck Converterke $12 \mathrm{~V}$ lalu akan mengisi Aki yang kemudian Aki akan mensuplay beban.

1) Panel Surya $200 \mathrm{Wp}$

Sumber listrik yang di pakai adalah panel surya 200 $\mathrm{Wp}$, dengan spesifikasi sebagai berikut:

Tabel 2

Spesifikasi Panel Surya

\begin{tabular}{lc}
\hline Merek & Solarland \\
\hline Model & SLP200S-24 \\
Tipe & Monocrystalline \\
Open Circuit Voltage (Voc) & $43.2 \mathrm{~V}$ \\
Optimum Operating Voltage (VMP) & $35.2 \mathrm{~V}$ \\
Short Circuit Current $(\mathrm{ISC})$ & $6.09 \mathrm{~A}$ \\
Optimum Operating Current $(\mathrm{IMP})$ & $5.69 \mathrm{~A}$ \\
Maximum Power at STC( $\left.\mathrm{P}_{\mathrm{maks}}\right)$ & $200 \mathrm{Wp}$ \\
Standard Test Condition $(\mathrm{STC})$ & $1000 \mathrm{~W} / \mathrm{m}^{2}, \mathrm{AM} 1.5 \& 25^{\circ} \mathrm{C}$
\end{tabular}




\section{B. Parameter Pengujian}

Parameter pengujian yang dilakukan adalah:

a) Pengambilan data pada panel surya

Langkah awal yang dilakukan yaitu melihat data base pada panel surya berupa :

1) Daya maksimun (Pmax)

2) Tegangan maksimum (Vmax)

3) Arus maksimum (Imp)

4) Tegangan Open Circuit (Voc)

5) Arus shortcircuit (Isc)

b) Pengambilan Data pada Aki

Pengambilan data pada beban yang di ambil dari Aki:

1) Tegangan aki (V)

2) Kapasitas arus (Ah)

c) Perancangan Desain Simulasi Pada Sofware PSIM

Merancang desain simulasi rangkaian sistem panel surya, yang berupa:

1. Desain Sel Surya

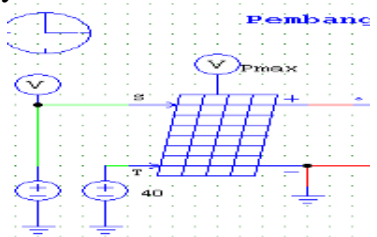

Gambar 7. Desain Panel Surya

Desain sel surya dilakukan di dalam software Psim yang sudah tersedia komponennya di menubar ElementsPower-Renawable Energy lalu Solar Module.

2. Desain Rangkaian Buck Converter

Menginput komponen-komponen untuk buck converter lalu membuat rangkaiannya pada software PSIM.

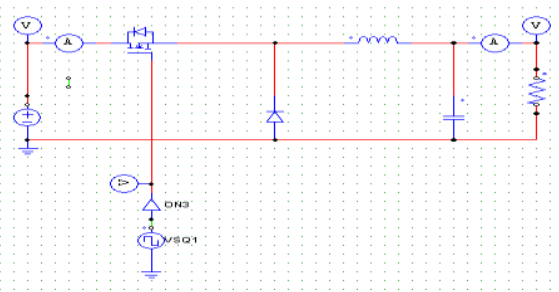

Gambar 8. Desain Rangkaian Buck Converter

3. Desain rancangan MPPT metode P\&O

Membuat desain rancangan MPPT metode $\mathrm{P} \& \mathrm{O}$ menggunakan software psim sesuai dengan algoritma pada gambar 2.9 Flowchart algoritma P\&O. Berikut adalah rancangan dan urutan cara kerja maximum power point tracking (MPPT) dengan algoritma perturb and observe $(\mathrm{P} \& \mathrm{O})$ menggunakan software PSIM.

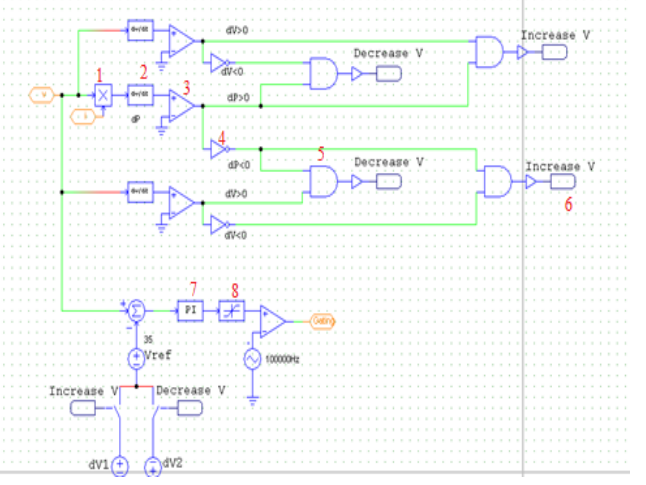

Gambar 9. Desain MPPT metode P\&O
Dalam rangkaian $\mathrm{P} \& \mathrm{O}$ terdapat beberapa komponen di antaranya 1. Multiplier 2. dv/dt function block 3 . Kompasator 4. Gerbang Not 5. Gerbang and 6. Label 7. PI controler 8. Limiter.

\section{HASIL DAN PEMBAHASAN}

\section{A. Pengimputan Datasheet Panel Surya dan Pengetasan Sistem}

Merancang desain sistem Panel surya menggunakan Sofware PSIM, kemudian meng-input datasheet panel surya yang akan di uji coba berupa:

1. Daya Maksimum $(\operatorname{Pmax})=200 \mathrm{Wp}$

2. Tegangan Maksimum $(\mathrm{Vmax})=35,2 \mathrm{~V}$

3. Arus Maksimum $(\operatorname{Imp})=5,69 \mathrm{~A}$

4. Tegangan Open Circuit (Voc) $=43,2 \mathrm{~V}$

5. Arus shortcircuit (Isc) $=6,09$ A

6. Standard Test Condition $(\mathrm{STC})=1000 / \mathrm{m}^{3}$, AM $1.5 \&$ $25^{\circ} \mathrm{C}$

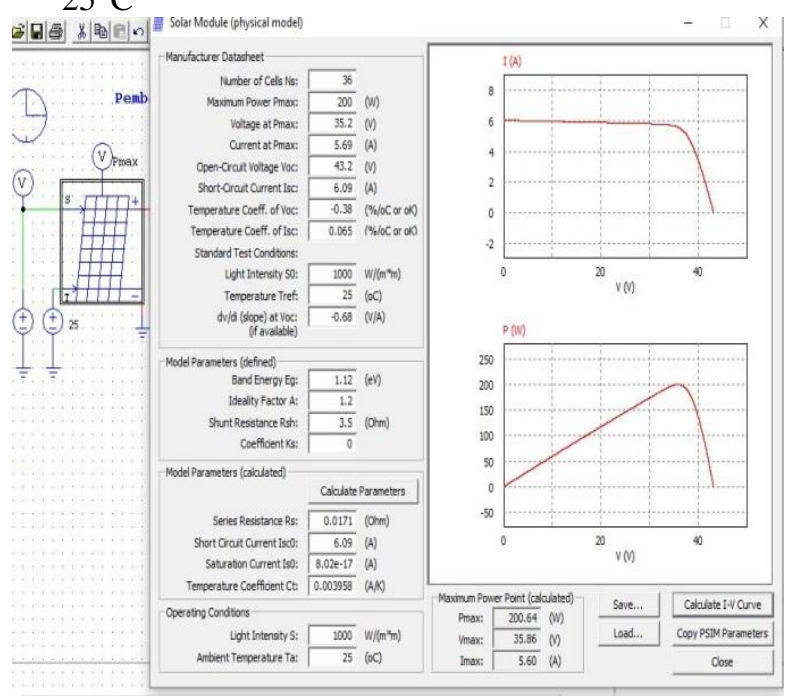

Gambar 10. Desain sistem dan solar modul sofware PSIM

Tabel 3

Hasil Pmax,Vmax dan Imax Pada pengaturan suhu dan intensitas berbeda

\begin{tabular}{|c|c|c|c|}
\hline \multirow[b]{2}{*}{ Intensitas } & \multicolumn{3}{|c|}{ Suhu } \\
\hline & $10^{\circ}$ & $25^{\circ}$ & $40^{\circ}$ \\
\hline \multirow{3}{*}{1000} & $P_{\max }=200.44 \mathrm{~W}$ & $P_{\max }=200.13 \mathrm{~W}$ & $P_{\max }=199.79 \mathrm{~W}$ \\
\hline & $V \max =35.48 \mathrm{~V}$ & $V \max =35.32 \mathrm{~V}$ & $V_{\max }=35.15 \mathrm{~V}$ \\
\hline & $I \max =5.65 \mathrm{~A}$ & $I \max =5.67 \mathrm{~A}$ & $I \max =5.68 . \mathrm{A}$ \\
\hline \multirow{3}{*}{900} & Pmax $=181.09 \mathrm{~W}$ & $P_{\max }=180.89 \mathrm{~W}$ & $P_{\max }=180.66 \mathrm{~W}$ \\
\hline & $V_{m a x}=35.75 \mathrm{~V}$ & $V_{\max }=35.58 \mathrm{~V}$ & $V \max =35.41 \mathrm{~V}$ \\
\hline & $I \max =5.07 \mathrm{~A}$ & $I \max =5.08 \mathrm{~A}$ & $I \max =5.10 \mathrm{~A}$ \\
\hline \multirow{3}{*}{800} & $P_{\max }=161.32 \mathrm{~W}$ & $P_{\max }=161.23 \mathrm{~W}$ & $P_{\max }=161.11 \mathrm{~W}$ \\
\hline & $V_{\max }=36.01 \mathrm{~V}$ & $V_{\max }=35.84 \mathrm{~V}$ & $V_{\max }=35.66 \mathrm{~V}$ \\
\hline & $I \max =4.48 \mathrm{~A}$ & $I \max =4.50 \mathrm{~A}$ & $I \max =4.52 \mathrm{~A}$ \\
\hline \multirow{3}{*}{700} & $P_{\max }=141.14 \mathrm{~W}$ & $P_{\max }=141.17 \mathrm{~W}$ & $P_{\max }=141.17 \mathrm{~W}$ \\
\hline & $V \max =36.26 \mathrm{~V}$ & $V \max =36.07 \mathrm{~V}$ & $V \max =35.88 \mathrm{~V}$ \\
\hline & $I \max =3.89 \mathrm{~A}$ & $I \max =3.91 \mathrm{~A}$ & $I \max =3.93 \mathrm{~A}$ \\
\hline \multirow{3}{*}{600} & $P_{\max }=120.56 \mathrm{~W}$ & $P_{\max }=120.72 \mathrm{~W}$ & $P_{\max }=120.85 \mathrm{~W}$ \\
\hline & $V \max =36.47 \mathrm{~V}$ & $V \max =36.28 \mathrm{~V}$ & $V \max =36.08 \mathrm{~V}$ \\
\hline & $I \max =3.31 \mathrm{~A}$ & $I \max =3.33 \mathrm{~A}$ & $I \max =3.35 \mathrm{~A}$ \\
\hline \multirow{3}{*}{500} & $P_{\max }=99.61 \mathrm{~W}$ & $P_{\max }=99.90 \mathrm{~W}$ & $P_{\max }=100.16 \mathrm{~W}$ \\
\hline & $V \max =36.65 \mathrm{~V}$ & $V \max =36.45 \mathrm{~V}$ & $V \max =36.24 \mathrm{~V}$ \\
\hline & $I \max =2.72 \mathrm{~A}$ & $I \max =2.74 \mathrm{~A}$ & $I \max =2.76 \mathrm{~A}$ \\
\hline \multirow{3}{*}{400} & $P_{\max }=78.30 \mathrm{~W}$ & Pmax $=78.73 \mathrm{~W}$ & $P_{\max }=79.13 \mathrm{~W}$ \\
\hline & $V_{\max }=36.77 \mathrm{~V}$ & $V_{\max }=36.56 \mathrm{~V}$ & $V_{\max }=36.50 \mathrm{~V}$ \\
\hline & $I \max =2.13 \mathrm{~A}$ & $I \max =2.15 \mathrm{~A}$ & $I \max =2.18 \mathrm{~A}$ \\
\hline \multirow{3}{*}{300} & $P_{\max }=56.70 \mathrm{~W}$ & $P_{\max }=57.27 \mathrm{~W}$ & Pmax $=57.82 \mathrm{~W}$ \\
\hline & $V \max =36.80 \mathrm{~V}$ & $V \max =36.56 \mathrm{~V}$ & $V \max =36.33 \mathrm{~V}$ \\
\hline & $I \max =1.54 \mathrm{~A}$ & $I \max =1.57 \mathrm{~A}$ & $I \max =1.59 \mathrm{~A}$ \\
\hline
\end{tabular}




\begin{tabular}{|c|c|c|c|}
\hline & $P \max =34.87 \mathrm{~W}$ & $P \max =35.60 \mathrm{~W}$ & $P \max =36.31 \mathrm{~W}$ \\
\hline \multirow[t]{3}{*}{200} & $V \max =36.60 \mathrm{~V}$ & Vmax $=36.35 \mathrm{~V}$ & $V \max =36.10 \mathrm{~V}$ \\
\hline & $\operatorname{Imax}=00.95 \mathrm{~A}$ & $\operatorname{Imax}=0.98 \mathrm{~A}$ & $\operatorname{Imax}=1.01 \mathrm{~A}$ \\
\hline & $P \max =13.11 \mathrm{~W}$ & $P \max =14.00 \mathrm{~W}$ & $P \max =14.87 \mathrm{~W}$ \\
\hline \multirow[t]{2}{*}{100} & $V \max =35.45 \mathrm{~V}$ & $V_{\max }=35.26 \mathrm{~V}$ & $V_{\max }=35.05 \mathrm{~V}$ \\
\hline & $I \max =0.37 \mathrm{~A}$ & $I \max =0.40 \mathrm{~A}$ & $\operatorname{Imax}=0.42 \mathrm{~A}$ \\
\hline
\end{tabular}

Ketika telah selesai membuat rancangan dan menginput datasheet panel surya, maka akan dilakukan uji coba untuk mendapatkan Pmax,Vmax dan Imax dengan mengubah intensitas cahaya matahari atau (S) dengan nilai Di asumsikan antara $1000-100$ dan suhu atau (T) dengan nilai $10^{\circ}, 25^{\circ}, 40^{\circ}$. Berikut adalah table hasil dari pengetesan program

\section{B. Hasil Desain Simulasi Buck Converter}

Perancangan desain buck converter menggunakan software PSIM. Sebelum meng-input data pada komponen rangkaian maka, dilakukan perhitungan manual untuk mendapatkan nilai yang di perlukan pada rangkaian buck converter berupa nilai pada $\mathrm{D}=$ dutycycle, $\mathrm{R}=$ Resistor, $\mathrm{L}=$ Induktor dan $\mathrm{C}=$ Kapasitor.

Diketahui :

$V_{\mathrm{i}}=35.2 \mathrm{~V}$

$V_{0}=12 \mathrm{~V}$

f $=100 \mathrm{Khz}$

$P=200 \mathrm{~W}$

$\% i_{L}=5 \%$

$\% v_{0}=5 \%$

Penyelesaian :

$\mathrm{D}=\frac{V_{0}}{V_{1}}=\frac{12 \mathrm{~V}}{35.2 \mathrm{~V}}=0,34$

$\mathrm{R}=\frac{V_{0}^{2}}{P}=\frac{12^{2}}{200}=0,72$

$i_{L}=\frac{V_{0}}{R}=\frac{12}{0.72}=16,6$

$\Delta \mathrm{i}_{L}=\% i_{L} x i_{L}=5 \% x 16,6=0.83$

$\mathrm{L}=\frac{\left(V_{i}-V_{0}\right] x D}{\Delta_{i} x f}=\frac{(35,2-12) x 0_{0}, 34}{0,82 x 100000}=9,50$

$\Delta \mathrm{V}_{0}=\% V_{0} x V_{0}=5 \% \times 12=0.6$

$\mathrm{C}=\frac{\Delta \mathrm{i}_{\bar{L}}}{\mathrm{Bx} \Delta \mathrm{V}_{\mathrm{g}} x \mathrm{f}}=\frac{0.83}{\mathrm{Bx} 0.6 \mathrm{x} 100000}=1_{s} 72$

Maka dari perhitungan di atas maka di dapatkan nilai untuk :

$\mathrm{D}=0,34$

$\mathrm{R}=0,72$

$\mathrm{L}=9,50$

$\mathrm{C}=1,72$

Setelah itu maka dilakukan penginputan nilai ke rangkain buck converter pada software PSIM dan melakukan pengukuran untuk uji coba apakah sesuai yang diinginkan yaitu pada tegangan input terbaca 35,2 V dan tegangan output terbaca $12 \mathrm{~V}$.

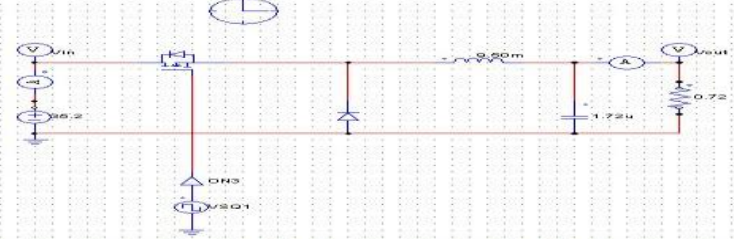

Gambar 11. Rangkaian Buck Converter pada software PSIM

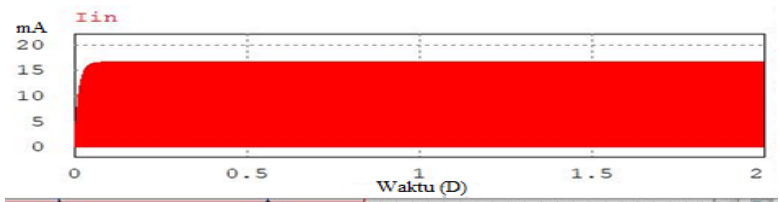

Gambar 12. Hasil pengukuran arus input rangkaian buck converter pada sofware PSIM

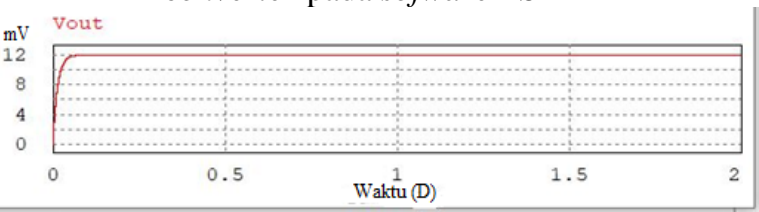

Gambar 13. Hasil pengukuran tegangan output rangkaian buck converter pada sofware PSIM

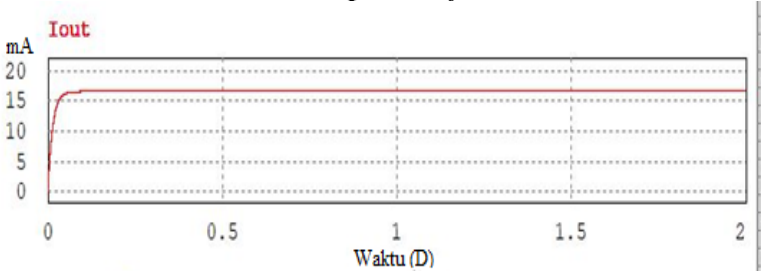

Gambar 14. Hasil pengukuran arus output rangkaian buck converter pada sofware PSIM

\section{Hasil Desain Simulasi MPPT Metode P\&O Pada Panel Surya}

Setelah diuji semua sistem sudah berhasil dan berjalan maka akan di lakukan pengujian dengan pengaturan dari berbagai kondisi radiasi $1000-100$ dan suhu $10^{\circ}, 25^{\circ}, 40^{\circ}$.

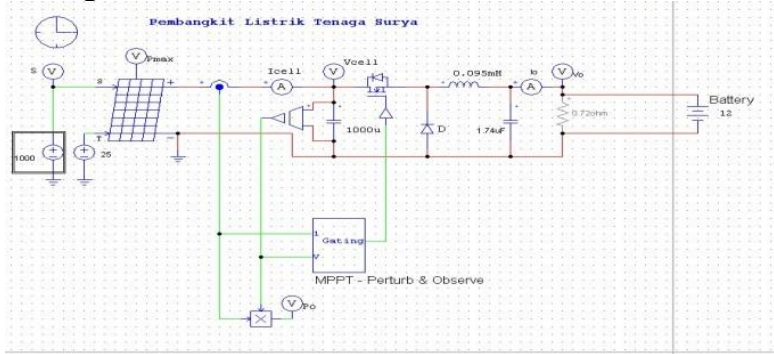

Gambar 15. Desain simulasi maximun power point tracking (MPPT) pada sel surya menggunakan metode $\mathrm{P} \& \mathrm{O}$

Berdasarkan dari hasil simulasi yang dilakukan, maka dapat dikatakan bahwa desain simulasi maksimum power point tracking (MPPT) menggunakan metode perturb and observe ( $\mathrm{P} \& \mathrm{O})$ pada software PSIM berhasil dan MPPT dapat men-track daya maksimum pada panel surya. Pada saat pengaturan kondisi dengan intensitas $S=1000$ dan suhu $\mathrm{T}=40^{\circ}$ didapatkan Pmax 201,5 W, Po 201,1 W dan waktu yang dibutuhkan MPPT untuk men-track adalah 0,003 detik, pada saat $\mathrm{S}=500 \mathrm{~T}=25$ maka didapatkan Pmax $=97,7 \mathrm{~W}$ dan $\mathrm{Po}=96,4 \mathrm{~W}$ dan waktu yang dibutuhkan adalah 0,006 detik. Dan pada kondisi $S=100$ $\mathrm{T}=10$ didapatkan $\mathrm{Pmax}=9,4 \mathrm{~W}, \mathrm{Po}=9,3 \mathrm{~W}$ dan waktu yang dibutuhkan MPPT untuk men-track adalah 0,04 detik. 
Tabel 4

Hasil waktu Pmax dan PO Pada pengaturan suhu dan intensitas berbeda

\begin{tabular}{|c|c|c|c|}
\hline Kondisi & Waktu & Pmax & Po \\
\hline $1000-40^{\circ}$ & 0,003 & $201,5 \mathrm{~W}$ & $201,1 \mathrm{~W}$ \\
\hline $1000-25^{\circ}$ & 0,003 & $200,6 \mathrm{~W}$ & $200,1 \mathrm{~W}$ \\
\hline $1000-10^{\circ}$ & 0,003 & $199,8 \mathrm{~W}$ & $198,9 \mathrm{~W}$ \\
\hline $900-40^{\circ}$ & 0,003 & $181,6 \mathrm{~W}$ & $181,1 \mathrm{~W}$ \\
\hline $900-25^{\circ}$ & 0,003 & $180,7 \mathrm{~W}$ & $179,8 \mathrm{~W}$ \\
\hline $900-10^{\circ}$ & 0,003 & $179,8 \mathrm{~W}$ & $178,4 \mathrm{~W}$ \\
\hline $800-40^{\circ}$ & 0,003 & $161,5 \mathrm{~W}$ & $160,6 \mathrm{~W}$ \\
\hline $800-25^{\circ}$ & 0,003 & $160,5 \mathrm{~W}$ & $159,2 \mathrm{~W}$ \\
\hline $800-10^{\circ}$ & 0,004 & $159,5 \mathrm{~W}$ & $157,7 \mathrm{~W}$ \\
\hline $700-40^{\circ}$ & 0,004 & $141 \mathrm{~W}$ & $140 \mathrm{~W}$ \\
\hline $700-25^{\circ}$ & 0,004 & $139,8 \mathrm{~W}$ & $138,4 \mathrm{~W}$ \\
\hline $700-10^{\circ}$ & 0,004 & $138,7 \mathrm{~W}$ & $136,8 \mathrm{~W}$ \\
\hline $600-40^{\circ}$ & 0,005 & $120,2 \mathrm{~W}$ & $119,1 \mathrm{~W}$ \\
\hline $600-25^{\circ}$ & 0,005 & $118,9 \mathrm{~W}$ & $117,5 \mathrm{~W}$ \\
\hline $600-10^{\circ}$ & 0,005 & $117,6 \mathrm{~W}$ & $115,6 \mathrm{~W}$ \\
\hline $500-40^{\circ}$ & 0,005 & $99,1 \mathrm{~W}$ & $98,2 \mathrm{~W}$ \\
\hline $500-25^{\circ}$ & 0,006 & $97,7 \mathrm{~W}$ & $96,4 \mathrm{~W}$ \\
\hline $500-10^{\circ}$ & 0,006 & $96,3 \mathrm{~W}$ & $94,5 \mathrm{~W}$ \\
\hline $400-40^{\circ}$ & 0,007 & $77,9 \mathrm{~W}$ & $77,1 \mathrm{~W}$ \\
\hline $400-25^{\circ}$ & 0,007 & $76,3 \mathrm{~W}$ & $75,2 \mathrm{~W}$ \\
\hline $400-10^{\circ}$ & 0,007 & $74,7 \mathrm{~W}$ & $73,3 \mathrm{~W}$ \\
\hline $300-40^{\circ}$ & 0,008 & $56,3 \mathrm{~W}$ & $55,8 \mathrm{~W}$ \\
\hline $300-25^{\circ}$ & 0,008 & $54,6 \mathrm{~W}$ & $53,9 \mathrm{~W}$ \\
\hline $300-10^{\circ}$ & 0,009 & $52,8 \mathrm{~W}$ & $52 \mathrm{w}$ \\
\hline $200-40^{\circ}$ & 0,013 & $34,7 \mathrm{~W}$ & $34,6 \mathrm{~W}$ \\
\hline $200-25^{\circ}$ & 0,014 & $32,8 \mathrm{~W}$ & $32,7 \mathrm{w}$ \\
\hline $200-10^{\circ}$ & 0,014 & $30,9 \mathrm{~W}$ & $30,7 \mathrm{~W}$ \\
\hline $100-40^{\circ}$ & 0,028 & $13,4 \mathrm{~W}$ & $13,3 \mathrm{~W}$ \\
\hline $100-25^{\circ}$ & 0,033 & $11,4 \mathrm{~W}$ & $11,3 \mathrm{~W}$ \\
\hline $100-10^{\circ}$ & 0,04 & $9,4 \mathrm{~W}$ & $9,3 \mathrm{~W}$ \\
\hline
\end{tabular}

Setelah di dapatkan Hasil Desain Simulasi MPPT metode P\&0 Pada Sel Surya Azzahra Hidroponik maka di dapatkan nilai tegangan,arus, dan daya yang di hasilkan oleh panel surya Azzahra Hidroponik dalam kondisi intensitas dan suhu yang berbeda. Dan di dapatkan bagaimanam Cara MPPT metode Perturb and Observe (P\&O) mentrack daya maksimum adalah, Sensor akan membaca tegangan (V) dan arus (I) kemudian untuk mendapatkan Daya (P), tegangan dikali arus. Ketika sudah mendapatkan dayanya atau $\mathrm{P}$ maka langkah selanjutnya meng-observasi $\Delta \mathrm{P}$ dan $\Delta \mathrm{V}$ dengan cara daya atau $\mathrm{P}$ di kurang dengan daya sebelumnya maka di dapatkan $\Delta \mathrm{P}$ begitu juga dengan tegangan. kemudian ketika $\Delta \mathrm{P}$ lebih besar dari 0 maka lanjut dilakuka mengobservasi $\Delta \mathrm{V}$. Jika hasilnya lebih besar dari 0 maka tegangannya akan di tambah (Vref + step). Jika 21 lebih kecil dari 0 maka tegangannya akan di kurang ((Vref step). Begitu juga ketika $\Delta \mathrm{P}$ lebih kecil dari 0 maka lanjut meng-observasi $\Delta \mathrm{V}$. Jika hasilnya lebih besar dari 0 maka tegangannya akan di tambah (Vref - step). Jika lebih kecil dari 0 maka tegangannya akan di kurang ((Vref + step). kemudian Vref akan di proses oleh control PI dan menghasilkan Duty cycle. Duty cycle inilah yang akan mengatur tegangan input Buck Converter sesuai dengan tegangan VMP yang dihasilkan oleh panel surya. Nilai Vref $=35 \mathrm{~V}$ di tentukan berdasarkan pengujian pemodelan panel surya.untuk nilai step $=0,1 \mathrm{~V}$ di tentukan berdasarkan rentang VMP pada antara $33 \mathrm{~V}-36$ $\mathrm{V}$ pada pengujian pemodelan panel surya.

\section{KESIMPULAN}

Berdasarkan dari hasil penelitian rancangan simulasi MPPT metode P\&O pada software PSIM, maka penulis dapat menyimpulkan sebagai berikut.

1. Semakin berkurangnya intensitas matahari maka semakin lama waktu yang dibutuhkan MPPT untuk men-track dan mendapatkan daya maksimal, hal ini dapat dilihat ketika pengaturan intensitas 1000 sampai 100 maka waktu yang dibutuhkan MPPT untuk mentrack mendapatkan daya maksimal adalah 0,003 detik sampai 0,004 detik.

2. Selisih daya Pmax dan Po pada pengaturan intensitas dan suhu yang berbeda dari $\mathrm{S}=1000-100$ dan suhu $\mathrm{T}$ $=40^{\circ}, 25^{\circ}$, dan $10^{\circ}$ selisih daya Pmax dan Po hanya 0-2 Watt.

3. MPPT men-track daya maksimum dengan pendekatan secara matematik dengan metode $\mathrm{P} \& \mathrm{O}$ untuk mendapatkan nilai daya maksimum dengan menaikkan dan menurunkan nilai sehingga mendapatkan daya maksimum

\section{UCAPAN TERIMA KASIH}

Terimah Kasih kepada Pemilik Azzahra Hidroponik akan kebaikannya mengizinkan saya sebagai peneliti untuk melakukan penelitian di Azzahra Hidroponik.

\section{REFERENSI}

[1] Utami, S. (2017). Implementasi Algoritma Perturb and Observe untuk Mengoptimasi Daya Keluaran Solar Cell Menggunakan MPPT. Jurnal Infotel, Vol.9 No.1.

[2] Pulungan, A. B., Sukardi, \& Ramadhan, t. (2018). Buck Converter Sebagai Regulator Aliran Daya Pada Pengereman Regeneratif. Jurnal EECCIS, Vol. 12 No. 2.

[3] Suryana, D., \& Ali, m. M. (2016). Pengaruh Temperatur / Suhu Terhadap Tegangan Yang Dihasilkan Panel Surya Jenis Monokristalin (Study Kasus:Baristand Industri Surabaya). Jurnal Teknologi Dan Inovasi Industri, Vol. 2. No 1.

[4] Setiono, I. (2015). Akumulator, Pemakaian dan Perawatannya. Metana, Vol.11 No. 01.

[5] Ernadi, D. A., Pujiantara, M., \& Purnomo, M. H. (2016). Desain Maximum Power Point Tracking untuk Turbin Angin Menggunakan Modified Perturb \& Observe (P\&O) Berdasarkan Prediksi Kecepatan Angin. Jurnal Teknik ITS, Vol. 5 No. 2. 